Uşak Üniversitesi Sosyal Bilimler Dergisi (2011) 4/1, 38-49

\title{
Karl Polanyi And The Great Transformation
}

\section{Ozan Örmeci}

Özet: 20. yüzyılın önde gelen iktisatçılarından olan Karl Polanyi (1886-1964), Büyük Dönüşüm adlı eserinde ortaya koyduğu özgün tezler ile halen kapitalizme en ciddi eleştiriyi getirmiş kişilerden biri kabul edilmektedir. Polanyi'nin klasik Marksist tezlerden farklılaşan görüşlerine kapitalizmin ciddi krizler yaşadığı 21. yüzyıl başlarında yeniden göz atmak faydalı olacaktır.

Anahtar Kelimeler: Karl Polanyi, Büyük Dönüşüm.

Keywords: Karl Polanyi, The Great Transformation.

\section{Introduction}

In today's world, liberalism and the belief in the idea of selfregulating market are accepted as inseparable parts of democracy and enjoy a widespread popularity around the world. Especially after the dissolution of Union of Soviet Socialist Republics (USSR), capitalism and free-market economics seem to have gained a complete victory against socialism and ideas about the necessity of interventionism in economics. However, it is also clear that although self-regulating markets have been in presence for centuries and have been applied nearly in all countries, social problems of people around the world do not decrease. IMF policies and the enmity towards interventionism were badly shaken again after the last economic crises. Anti-liberal and anti-globalist ideas have been gaining power in the last years. In fact, the counter movement against liberal economics gained important support in the early 1900s after the Great Depression and the Second World War and forced capitalist countries to adopt welfare regimes until the 1980s when neo-liberal economics has began to dominate the intellectual and political life again.

Karl Polanyi is known as one of the most famous economists of the world who strongly criticized liberalism and the idea of self-regulating market. Polanyi's masterpiece The Great Transformation is still accepted as one of the most powerful critiques of liberal economics and many writers from different political backgrounds refer to this book while criticizing the dominant liberal economic understanding. The Great Transformation is a very rich and complex book in which Polanyi analyzes the evolution of the free-

*Dr.,Uşak University Department of Public Administration 


\section{Ozan ÖRMECİ 39}

market ideology and the counter movement against the damages of liberal economics. Although Polanyi called himself as a socialist, his ideas are very dense and it is not easy to label him as a defender of certain ideology. He was certainly not a capitalist; he had many things in common with famous Karl Marx and some intersecting points with John Maynard Keynes. However, his theoretical position can be claimed to be original rather than a part of a certain school. We can call him as a humanist because of his anthropocentric thinking. Polanyi puts humans and well-being of them at the center of his theory. He sees everything (democracy, economics, state) as a mean for people's happiness, not as an end. His writings are still very popular among anti-liberals, anti-globalists, environmentalists, anthropologists and left-wing political writers. In addition, in the age of globalization during which we observe a rise in the quantity of reactions against international financial and economic system, Polanyi's book deserves a careful analysis.

This article aims to make a detailed analysis of Karl Polanyi's The Great Transformation. I am going to being with a short biography of Polanyi and some information related to the book. I will then focus on the important parts of the book and explain the evolution of free-market economics and liberal thought, fundamental problems in this ideology and the emergence of the counter movement in the light of Polanyi's writings.

\section{Biography}

Karl Polanyi was born in 1886 inBudapest, in a family remarkable for its social engagement and intellectual achievements. His brother Michael is still an important philosopher of science and his daughter Kari Polanyi is a distinguished economist who works as the head of Karl Polanyi Institute in Canada. Polanyi appeared as an important socialist figure in the Hungarian intellectuals circles in the 1910s. After the First World War when repressive Miklos Horhty period took place in Hungary, Polanyi took refuge in Austria. However, when Hitler came to power in Germany Polanyi had to escape to England to develop his socialist views freely. He worked in the Universities of Oxford and London as an economics lecturer. After the Second World War he fled to USA and began to work in the ColumbiaUniversity. He published The Great Transformation in 1944 and became an important figure in the anti-liberal wave. He became a friend of John Maynard Keynes at those years. However, during oppressive McCarthy regime Polanyi had some troubles with the American government due to his -now famous- anti-liberal views and the deeds of her socialist 
activist wife Ilona Polanyi. Polanyi went this time to Canada and spent the rest of his life there. He continued to develop his theory and even established his own institute; Karl Polanyi Institute to develop this theories. Polanyi died on 1964 inCanada.

\section{The Great Transformation}

The Great Transformation, Polanyi's most famous work, is composed of three main parts. First and the third parts focus on the immediate circumstances, reasons that prepared necessary grounds for First World War, Great Depression, the rise of fascism in Europe, the Second World War and the emergence of the New Deal in USA. Part two consists of Polanyi's deep ideas and analysis of the development of liberal thought and the idea of self-regulating market. Polanyi in this longest part of the book, gradually examines the development of European countries and show how the selfregulating market utopia created problems in European societies and in the world. He also dealt with the evolution of counter movement against freemarket economics by substantiating his arguments with concrete examples. His key concepts like embeddedness and double movement are explained in this second part of the book.

\section{Economic History}

In Karl Polanyi's view, human nature, whether is good or selfish, is not directed towards economic ends. He asserts that human passions are directed towards non-economic ends rather than economic ends (Polanyi, p. 49). He thinks that men need to have access to economic ends only for safeguarding their social standings. In Polanyi's theory economy is subordinated to society in general and thus, economic needs shape individuals' behaviors only when they directly affect their social positions, social relations. He argues that in the early communal life, men did not care for economic gains because in their lives, there were more important values like cooperation, benevolence and respect. In this sense, Polanyi's arguments can resemble to Marxist understanding of the earlier tribal communal life but there is a fundamental difference between these ideas. Polanyi's economic determinism was very weak against orthodox Marxism since Polanyi never saw economics as the sole dynamic power behind social relations and the political structure. In Polanyi's idea, economics was a part of broader social life. He criticized Marxists and liberals for reading history from an economical perspective by writing "Economic liberalism misread the history of the Industrial Revolution because it insisted on judging social events from the economic viewpoint" (Polanyi, p. 36). Polanyi thought that 


\section{Ozan ÖRMECİ 41}

social relations were shaping economics until the emergence of the idea of self-regulating market. In addition, unlike Marx, Polanyi never saw capitalism as a positive step for a better world order.

In the tribal life, economic gains were not important because the society was trying to keep all of its members alive and were sharing things equally. However, if someone did something against the tribal norms e.g. stealing from another person, this person was punished communally. Social obligations of individuals were reciprocal so, this was creating a pressure on people to eliminate self-interest. We can resemble this idea to the "organic solidarity" conception of Emile Durkheim because in both theories, people's necessity on each other was directing them to give up or to prevent to evolve their self-interests. Reciprocity and fair distribution were the dominant aspects of the earlier communal life. In tribal life, a man was willingly to have a good-looking, fertile garden not because of economic gains but rather for his prestige among the community (Polanyi, p. 50). This man would enjoy to be known for the quality of his gardening skills. Following Aristotle's criterion, Polanyi says that in tribal societies as well as other stages until free-market economics, the principle of use was dominant not the principle of gain. Affected by Aristotle, Polanyi put forward the idea that like households economics should be based on subsistence and should not spoil the social relations like in the free-market system (Polanyi, pp. 56-57). In his idea as political, social animals human beings need to live communally as a part of society not as individuals competing in the market. But how society evolved in such a way that economics have become the ruling aspect of social life?

According to Karl Polanyi, the first form of economics was related to "household affaires" which is based on autarchy and the principle of subsistence. Next step was the barter system, which is based on symmetrical trade relations. People were trading things they do not need in return to things they needed. Thereafter, with the emergence of mercantilism, the state began to control all local markets and created a single national market. This system was based on redistribution in which state was playing an active role. In all of these stages the dominant motive of people for engaging in economical relations was the principle of use. Only after the mercantilist era, with the emergence of Industrial Revolution and self-regulating market understanding, the principle of gain appeared and changed everything that existed before. The aim of this new understanding was not the well-being of the society but rather was to transform the society according to its rules. 
Using Polanyi's term, this "satanic mill" aimed at establishing a single global market which was a "stark utopia" according to Polanyi.

In Polanyi's theory communal life and redistribution continued to exist in feudal societies. In feudal societies, there were local markets but their role was not to shape the society. Instead of this, society was shaping the market for its benefit. Principle of use was superior to the principle of gain. Even in the early mercantilist ${ }^{1}$ period trade was perceived as something symmetrical and autarchy was the dominant principle. The aim of the trade was to import lacking goods by selling excessive common goods in this geography. Mercantilism achieved to create a national market which replaced local markets that existed during the feudal times. Centralized administration was responsible for the redistribution of economic gains. In the mercantilist system, the state was able to control the market and the market was embedded into society. In a sense interventionism and market grew up together during the mercantilist era. In Polanyi's thinking, mercantilism was caused by the necessity of trade between different climate zones and local exchange between town and countryside. During mercantilism there was no real competition and if competition was causing problems, it had to be eliminated. Due to mercantilism, craft guilds came under the state control (Polanyi, p. 69).

Polanyi says that until the emergence of so-called self-regulating market, markets were not more than the "accessories of economic life" (Polanyi, p. 71). However, starting from the late mercantilist period accumulation of wealth increased enormously among traders. Through colonization European countries and European traders under the protection of the state, made important accumulations. However, their primary motive was still not to create a trickle-down economics. Only after the emergence of Industrial Revolution, the total structure of the society and state began to change. Newly formed bourgeois class was now running after profit maximization and the principle of gain affected by the writings of liberal thinkers who began to emphasize the necessity of government to take its hands from economics. This was just the beginning of laissez-faire understanding.

Polanyi defines market economy as "an economic system controlled, regulated, and directed by market prices; order in the production and distribution of goods is entrusted to this self-regulating mechanism"

${ }^{1}$ Mercantilism: The theory and system of political economy prevailing in Europe after the decline of feudalism, based on national policies of accumulating bullion, establishing colonies and a merchant marine, and developing industry and mining to attain a favorable balance of trade. 


\section{Ozan ÖRMECI 43}

(Polanyi, p. 71). Market economy believes in the market balance which would determine the necessary price of goods or services in the market through the relation between supply and demand. Market economy offers a progress which would be realized via economic growth when all individuals try to maximize their own benefit. Like famous liberal economist Adam Smith explained by his concept of "invisible hand", market balance is thought to work automatically and determine prices in the market. It was accepted that the whole society would gain from the competitive environment in which all firms, individuals try to maximize their own benefit. For Polanyi market economics is the reversal of the whole economic tradition of human civilization because it tries to embed society to the rules of disembedded and uncontrolled free-market. "Market economy means no less than the running of society as an adjunct to the market. Instead of economy being embedded in social relations, social relations are embedded in the economic system" (Polanyi, p. 60). Polanyi points out that this implies a great transformation in the life of humans because, "a market economy can exist only in a market society" (Polanyi, p. 74). This was the first great transformation when the nature of the society was tried to be changed by free-market economics. "The self-regulating market was unknown; indeed the emergence of the idea of self-regulation was a complete reversal of the trend of development" (Polanyi, p. 71). In Polanyi's thought self-regulation implies that "all production is for sale on the market and all incomes derive from such sales" (Polanyi, p. 72). According to self-regulation, not only commodities but also labor, land and money would also find their worth in the market. The commodification of land would be in the form of rent, labor in the form of wages and money in the form of interest. The commodification of these three "fictitious commodities" constitutes a very important place in Polanyi's theory.

\section{Commodification}

Polanyi from his humanist point of view rejects the commodification of humans and nature in the market. There are some similar points between Marxism and his arguments on this point but Marx saw this as a positive development for reaching the communist society. Although Polanyi's ideas are not that clear, he probably favors a return to pre-capitalist society because he sees capitalism as treason to human nature and civilization. As far as Polanyi is concerned, if the market has to determine all prices, market would also have to determine prices in the labor, land and money market and this would bring the commodification of these three. Polanyi does not 
believe that human beings and natural surroundings can be sold as commodities because it is not moral and it would have terrible consequences. That is why he called humans, nature and money as "fictitious commodities".

Polanyi sees commodification firstly as a moral problem. His humanist understanding does not allow him to accept the sale of human labor in the market. In his theory, making humans and nature as commodity would be to change one of the most basic rules of human civilization until this time and to spoil the sacred dimension, preciousness of human and natural life. Second important problem was related directly to economics and social problems. Polanyi thought that without state interventions, freemarket economics would face problems like inflation, deflation, unemployment and pollution. This would cause important social problems like "perversion, crime and starvation" among people (Polanyi, p. 76). Similarly, nature would be destroyed as a result of this commodification process and rivers would be polluted, raw materials would be destroyed. His criticism at this point is frequently used nowadays in environmentalist studies.

\section{Interventionism}

Polanyi also underlines that interventionism was not planned but rather caused by the needs of the society unlike laissez-faire economics which was planned by liberal economists who try to realize a "stark utopia". Polanyi claims that "laissez-faire was planned but planning was not" (Polanyi, p. 141). By saying this, Polanyi means that self-regulating market utopia was not developed naturally but rather created by liberal thinkers and supported by bourgeois class. Polanyi believed that liberal writers tried to show this process as a natural outcome but it war artificial and aiming to change the society from above and enslaves it to the market. Polanyi struggled to show how market society would perish and the dichotomy between people's economic and private lives would cause social and psychological problems. According to him, in a market society people were divided into two parts, a part that seeks for self profit maximization and the other part that appears in the social life, a benevolent citizen, a father, a friend, a lover.

\section{Industrial Revolution}

Polanyi also explains the events that took place during the Industrial Revolution. Legal and socio-economic problems constitute main subject of this part. He tries to show how society was hit badly from wild capitalism 


\section{Ozan ÖRMECI 45}

and the legal procedures that protect this system such as the Corn Law in 1815 and the Poor Law in 1834 inGreat Britain. These events prepared necessary grounds for the second great transformation. This time it was the society who was showing reactions against the evils of the satanic mill. In Polanyi's view, the modern society has been governed by two dynamics (double movement) since the Industrial Revolution. The first one is the idea of self-regulating market which has become the dominant ideology and the second is the counter movement that aims to protect the society from the negative effects of the first movement. Free-market ideology spoiled the social fabric of nations by making the self-regulating market an end rather than a mean for humans. Polanyi here uses Robert Owen's ideas about the necessity of interventionism. "Robert Owen's was a true insight: market economy if left to evolve according to its own lands would create great and permanent evils" (Polanyi, p. 136). Polanyi asserts that the counter movement has been trying to check the actions of the market and to change some policies by various ways (democratic syndical rights, revolution etc) to make the system less evil.

Especially after the emergence of Marxist movement, those who suffered most from this unfair system, the proletariat class began to challenge the legitimacy of the system. Orthodox Marxists in the $19^{\text {th }}$ and early $20^{\text {th }}$ century were supporting oppressive capitalist policies because they were thinking that socialist revolution would replace capitalism naturally as the consequence of the inherent problems of capitalism. However, starting from the $20^{\text {th }}$ century Marxists and social democratic movements has started to use reformist democratic ways (Polanyi, p. 139). Polanyi does not agree with Marx and other Marxist writers that the counter movement was solely about worker class' reactions against laissez-faire. Environmentalists, landed classes, agrarians and even conservative groups also supported this counter movement against the perils of capitalism. Sometimes even local trading classes which were negatively affected from the global market also supported interventionism. Polanyi always emphasized the importance of proletariat in this reaction but he thought that the reaction was coming from the society totally except a small class of people who profit from the situation. In his thought, the counter movement was broader than a class interest movement because it was related more with the social calamity than economic inequality (Polanyi, p. 164). Utilitarians were supporting the self-regulated market ideology because they believed in the liberal doctrine which is based on the idea that society would totally gain from the free-market economics. However, Polanyi 
shows the clear difference between utilitarians and pro laissez-faire utopians. "To the typical utilitarian, economic liberalism was a social project which should be put into effect for the greatest happiness of the greatest number; laissez faire was not a method to achieve a thing, it was the thing to be achieved" (Polanyi, p. 145). However, because of the extreme contradictions and problems in the laissez-faire, counter movement's effect began to grow and the clash between these counter movements caused the emergence of the World Wars, economic crises and the collapse of democracy in many parts of the world.

\section{Self-Regulating Market}

Polanyi begins to the first chapter of his book by stating that the "19th century civilization has collapsed" (Polanyi, p. 3). Before analyzing the reasons that prepared this collapse, Polanyi names four key institutions of the $19^{\text {th }}$ century order. These are balance of power system, international gold standard system, self-regulating market and the liberal state. The most important part of this system was the self-regulating market. Polanyi believes that it was this invention that led to the appearance of a new civilization. The gold standard system was an extension of the selfregulating market to create an international market. Balance of power system was about the "Concert of Europe", a superstructure to prevent the collapse of this system because of the problems between strong countries. And lastly, liberal state was the necessary political domination system in countries to adopt self-regulating market. Polanyi then begins to explain 100 years of peace in Europe between the years 1815 and 1914.

Starting from the 1815's Vienna Congress, a century lasting peace took place between European powers. European capitalist countries were afraid of a great war between themselves especially after the technological advances in the military industry. Their economies were growing with the establishment of new factories and the flow new raw materials from colonized or exploited countries. They were also agreed about the partition of Ottoman lands. By 1881's Decree of Muharrem, Ottoman economy was began to be controlled by Public Debt Administration. Peace between Great Powers was crucial for the economic situation because it was very hard to make international monetary system function during a war. The Hundred Years Peace does not imply the lack of wars on the periphery, or between a Great Power and a small state, but does preclude the large-scale wars that are bad for business. Polanyi here agrees with Lenin about the nature of finance capital. They both blame finance capital for being the architect of wars, imperialism and expansionist policies (Polanyi, p. 16). Polanyi claims 


\section{Ozan ÖRMECI 47}

that even peace was arranged by finance capital. In Polanyi's view, this 100 years peace in Europe is a very important success and is even more important than the Holly Alliance. "But the achievement of the Concert of Europe was incomparably greater than that of the Holly Alliance; for the latter maintained peace in a limited region in an unchanging continent, while the former succeeded in the same task on a world scale while social and economic progress was revolutionizing the map of the globe" (Polanyi, p. 18). Polanyi also underlines the importance and success of German chancellor Bismarck's realistic balance policies. Polanyi describes the Concert like a loose confederation of independent powers. However, towards the end of $20^{\text {th }}$ century, colonial rivalries started to become a problem between Great Powers. In addition, in all countries the counter movement was gaining power especially in the form of revolutionary socialism. Moreover, international gold system was creating instabilities in European economies.

The first shock occurred within the national spheres. Some currencies such as the Russian, the German and the Hungarian had to be devaluated. These crises were affecting Great Powers' economies too due to international financial and monetary system. Governments around the world began to take precautions against the dangers of economic dependency to the global market. In some countries due to economic problems and internal struggles, authoritarian governments replaced democratic governments. First World War was nearly welcomed by all countries in which there were endless economic problems. After the First World War, many changes occurred in the world order. Tsarist Russia was collapsed and Marxist Bolsheviks acquired the ruling power. OttomanState began to dissolve and Great Powers engaged actively in the partition of Ottoman lands. Defeated countries such as Germany were forced to sign peace agreements with very heavy conditions. The world economy was shaken again in 1929 because of the Great Depression. All economies were hit badly from this crisis and the trust towards liberalism was decreased enormously. This led to the emergence of authoritarian and even totalitarian, expansionist regimes all over the world like in Japan, Germany and Italy. According to Polanyi, the rise of fascism was the result of the liberal utopia of self-regulating market. These events prepared necessary grounds for the Second World War and in few years, the biggest war ever made started between Great Powers. This led to the death of 50 million people and enormous sufferings of people. After the war, Keynesian economics which was advising the necessity of government's engagement in 
economics gained popularity all around the world. The utopia of selfregulating market was replaced by welfare states and even by "New Deal" in USA. This wave continued until the late 1970's in Europe.

\section{Critique}

First of all, Karl Polanyi's writing is very powerful and the use of words like "satanic mill", "stark utopia" strengthens his ideas. However, the book is not very well organized for readers who are used to the linear historical understanding in Western thought. Polanyi's main idea is that human nature is not based on the greed for economic gains but this was added to social life after the Industrial Revolution and self-regulating markets. Polanyi from his humanist point of view rejects the modern liberal economy which reduces men and nature to commodities that can be sold in the market. In his opinion, politics, economics, laws and everything should be implemented for the society not as unchangeable principles. He defines free-market economy as a utopia and does not believe that this kind of an economic understanding can last for long years without serious problems. The term utopia is often associated the leftist ideology probably because of Thomas More's work but Polanyi uses it for liberalism. Utopia in his meaning is not something desirable but rather something that is crazy, unrealistic and impossible. Polanyi thinks that free-market will not only spoil the human nature and create social problems, but also will cause economic problems and lead to the radicalization of the counter movement. Natural problems will be another important damage of the free-market in his idea. He explains the rise of fascism in terms of people's reaction towards self-regulating market. He adds that not a single self-regulating market has ever existed and in the most liberal economies governments still have to play an important role.

While criticizing liberalism powerfully, Polanyi fails to present a concrete alternative economic strategy. While criticizing liberalism powerfully, Polanyi fails to present a concrete alternative economic strategy. We know that he is in the favor of interventionism and welfare state but we cannot be sure whether he dreams of a planned economy or not. The closest ideology to Polanyi's thought can be that of social democracy which tries to protect the lower classes from the perils of free-market economy without abolishing private property or free-market under state's supervision. Polanyi blames free-market economy as the architect of wars, imperialism, economic crises and the rise of authoritarian regimes. He praises old type of subsistence economy which is based on the well-being of society and the redistribution of gains. He asserts that countries and societies are their own 


\section{Ozan ÖRMECI 49}

subjective conditions and universal theories may not cover the whole truth. In this respect, he was very much liked by anthropologists and relativists. Although Marxists profit from some of his ideas, Polanyi can never said to be a Marxist because he rejects economic determinism and does not see capitalism as a positive step. Polanyi's book is still very important because what he called as self-regulating market or Washington consensus in today's terminology is still powerful and many people believe in the success of freemarket economy without governmental control. Still IMF policies are implemented and mostly failed all around the world. Maybe a return to subsistence economy or tribal life is impossible but at least negative effects of the free-market can be reduced. The main problem with neo-liberalism is that like Polanyi mentioned in his book, it gives no importance to human factor which should be the basis of policies. Unemployment of thousand people can be just a statistics for government or IMF however; it means the troubles of thousands of people in the society. Economics cannot be above humans just like other political or economic regimes because they are created for humans to live in better conditions.

\section{Bibliography}

- Polanyi, Karl, “The Great Transformation”, 2001,

Boston: Beacon Press 